\title{
POESIA E EPIFANIA
}

\section{POETRY AND EPIPHANY}

\section{Cleide Maria de Oliveira*}

RESUMO: O artigo aborda alguns aspectos temáticos da poética de Adélia Prado, em especial a religiosidade mística que permeia essa obra. Pretende-se demonstrar que, ainda que intrinsecamente religiosa, a obra adeliana não é ingênua ou catequética, na medida em que se enraíza fortemente em uma corporalidade extrema que assume corpo e palavra como abertos para o sagrado.

PALAVRAS-CHAVE: Adélia Prado, poesia, mística, corporalidade.

ABSTRACT: The article discusses some aspects of the poetic theme of Adelia Prado in particular the mystical religiosity that permeates that work. We intend to demonstrate that, even intrinsically religious, adeliana poetry is not naive or catechetical, since it is strongly rooted in an extreme corporeality assumes that body and language as open to the sacred.

KEYWORDS: Adélia Prado, poetry, mysticism, corporeality

* Universidade Federal do Rio de Janeiro (UFRJ), Rio de Janeiro/RJ. Professora Substituta de Literatura Brasileira do Departamento de Vernáculas. Doutora em Estudos de Literatura pela PUC-Rio. Email: Cleideoliva@yahoo.com.br. 



\section{Convertendo o caos em cosmos}

Um dos aspectos mais significativos da poesia de Adélia Prado é o apelo a uma totalidade da experiência do real e do existir que parece distante das pretensões cognitivas e estéticas da contemporaneidade. Sua poética é testemunho da presença/nostalgia de uma sacralidade e de uma inteireza que se costuma associar às sociedades pré-modernas, elaborando um espaço em que a linguagem deixa de ser representativa e referencial para se tornar palavra mítica, inteira e religiosa, no sentido em que pretende re-ligar o leitor a uma dimensão desconhecida da língua, que deixa de ser um conjunto de signos convencionais e arbitrários para constituir um universo em que palavras e coisas se irmanam, e a realidade, porque sagrada, se oferece sem fraturas.

Quando penso em inteireza, quero dizer algo mais do que a recuperação e a legitimação do corpo e do feminino desejante que encontramos em Adélia. Inteira é a forma de experienciar a realidade, "como se" nela não houvesse fissuras, de uma forma mágica e mítica, conforme definição de Adolpho Crippa:

[...] a realidade que a experiência mítica alcança, chame-a divina, humana ou mundana, apresenta-se como uma totalidade cósmica, viva. Em conseqüência, a vida, individual e coletiva, determinada por essa consciência, estará sempre vinculada a uma totalidade ontológica (1975, p. 37). 
O universo lírico-ficcional de Adélia se inscreve no campo do sagrado, da totalidade. Em diversos momentos percebemos que ela procede a uma sacralização do espaço, e essa cosmogonização é realizada distendendo os limites da corporalidade até o ponto em que o corpo e seus signos culturais e ideológicos se transformem em espaço sagrado no qual o divino se manifesta. Aparentemente, Adélia faz opção por uma vivência "religiosa", no sentido de um existir não fragmentado e pleno de realidade. A identificação entre sagrado, realidade e poder própria da existência religiosa vem acompanhada de uma identificação entre o profano e a pseudorrealidade do factual que é identificada ao caos amorfo, ao não ser absoluto. O estudioso do fenômeno religioso Mircea Eliade chama atenção para o fato de que essa adesão ao tempo e às realidades sagradas não significa uma recusa do mundo "factual", uma evasão no imaginário, implicando inautenticidade existencial, para falarmos em termos sartreanos. Ao modo de existir religioso não falta, adverte Eliade, nem autenticidade, nem profundidade e se a nós, modernos, essa opção de vida parece uma recusa a assumir responsabilidades pelo próprio ser-no-mundo e uma autoalienação, é porque não compreendemos que se trata de um tipo de responsabilidade diferente. $\mathrm{O}$ homem religioso se sente irmanado e coparticipante da realidade cósmica, que é percebida como hierofânica, ${ }^{1}$ magicamente

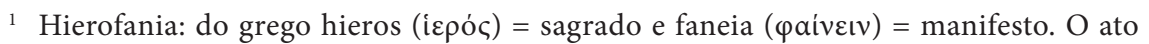
de manifestação do sagrado. Termo cunhado por Eliade para explicar a relação que se estabelece entre o humano e a manifestação do sagrado: "O homem toma conhecimento do sagrado porque este se manifesta, se mostra como qualquer coisa de absolutamente diferente do profano. A fim de indicarmos o acto da manifestação do sagrado propusemos o termo hierofania. O termo é cômodo porque não implica qualquer precisão suplementar: exprime apenas o que está implicado no seu conteúdo etimológico, a saber, que algo de sagrado se nos mostra. Poderia dizer-se que a história das religiões - desde as mais primitivas às mais elaboradas - é constituída por um número considerável de hierofanias, pelas manifestações das realidades sagradas. A partir da mais elementar hierofania - por exemplo, a manifestação do sagrado num objeto qualquer, uma pedra ou uma árvore - e até à hierofania suprema que é, para um cristão, a encarnação de Deus em Jesus Cristo, não existe solução de continuidade. Encontramo-nos diante do mesmo ato misterioso: a manifestação de algo 'de ordem diferente' - de uma realidade que não pertence ao nosso mundo - em objectos que fazem parte integrante do nosso mundo 'natural', 'profano'. O ocidental moderno experimenta um certo mal-estar diante de inúmeras formas de manifestação do sagrado: é-lhe difícil aceitar que, para certos seres humanos, o sagrado possa manifestar-se em pedras ou em árvores, por exemplo. Mas [...] não se trata de uma veneração da pedra como pedra, de um culto da árvore como árvore. A pedra sagrada, a árvore sagrada, não são adoradas como pedra ou como árvore, são-no justamente porque 
aberta à sua participação, e é de forma coparticipante a essa realidade que ele articula seu agir.

Ao contrário, parece-nos que, ainda aqui, é possível observar a obsessão ontológica, que aliás pode ser considerada uma característica essencial do homem das sociedades primitivas e arcaicas. Porque, em suma, desejar estabelecer o Tempo das origens é desejar não apenas reencontrar a presença dos deuses, mas também recuperar o Mundo forte, recente e puro, tal como era in illo tempore. É, ao mesmo tempo sede do sagrado e nostalgia do Ser. No plano existencial, esta experiência traduz-se pela certeza de poder recomeçar periodicamente a vida com o máximo de "sorte". É, com efeito, não somente uma visão otimista da existência, mas também uma adesão total ao Ser. Por todos os seus comportamentos, o homem religioso proclama que só acredita no Ser e que sua participação no Ser lhe é afiançada pela revelação primordial da qual ele é o guardião. A soma das revelações primordiais é constituída por seus mitos (ELIADE, 2001, p. 83-84, grifo do autor).

Interpreto que a opção adeliana pelo inteiro e pelo sagrado põe a desnudo uma estrutura básica do espírito humano, ou seja, entendo que o apelo religioso seja constituinte de nossa identidade, algo como uma espécie de constante antropológica, mesmo em caóticos tempos pós-modernos. Aliado ao instinto religioso, o erotismo e a poiésis (ou poéticas, como nos diz Antônia, uma das personagens de Adélia) seriam outras formas de experienciar a inteireza da realidade - o realíssimo -, que constituiriam o pano de fundo das nossas construções socioculturais. Tanto a linguagem mítico-poética quanto o erotismo se apresentam como um salto para a alteridade, para o completamente outro, e nesse sentido exigem do humano um movimento de pôr-se em risco, de desprendimento de si em busca de

são hierofanias, porque 'mostram' qualquer coisa que já não é pedra nem árvore, mas o sagrado, o 'ganz andere'. Nunca será de mais insistir no paradoxo que toda a hierofania constitui, até a mais elementar. Manifestando o sagrado, um objeto qualquer torna-se outra coisa, e, contudo, continua a ser ele mesmo, porque continua a participar do seu meio cósmico envolvente. Uma pedra sagrada nem por isso é menos uma pedra; aparentemente (com maior exatidão: de um ponto de vista profano) nada a distingue de todas as demais pedras. Para aqueles a cujos olhos uma pedra se revela sagrada, a sua realidade imediata transmuda-se numa realidade sobrenatural. Por outros termos, para aqueles que têm uma experiência religiosa, toda a Natureza é susceptível de revelar-se como sacralidade cósmica. O Cosmos na sua totalidade pode tornar-se uma hierofania" (ELIADE, 2001, p. 25). 
uma experiência radical de totalidade, em que morte e vida se encontram e se intersignificam.

A narrativa poética de Adélia Prado constrói um universo em que se recupera a sacralidade de todas as dimensões da experiência humana. Como Mircea Eliade ${ }^{2}$ irá postular, para o homem religioso todas as suas experiências existenciais são passíveis de serem sacralizadas: o comer, o beber, os ciclos de vida e de morte, o sexo, o trabalho, a habitação de uma casa, o casamento, a guerra etc. A poesia de Adélia é religiosa porque testemunha um pulsar do mistério da vida: "A poesia me faz perceber a pulsação das coisas. Isso é que é poesia, e a isso chamo também de experiência religiosa" (2004). O universo ficcional criado por Adélia é, em palavras do filósofo theco Vilém Flusser, ${ }^{3}$ profundo e opaco, isto é, permeado de mistério; e a sede de "realidade" que encontramos aqui é a mesma obsessão ontológica que Mircea Eliade definiu como própria do homem religioso. O mundo, tocado pela poesia, torna-se mágico, harmônico, integrado. Veja-se um exemplo dessa afirmação no poema "A despropósito" (PRADO, 1986), que ilustra exemplarmente o deslocamento que a poeta opera no evento epifânico, que passa a se dar no banal cotidiano:

Olhou para o teto, a telha parecia um quadrado de doce.

$\mathrm{Ah}$ ! - falou sem se dar conta de que descobria, durando desde

2 “[...] o homem religioso é acessível a uma série infinita de experiências que poderiam ser chamadas de 'cósmicas'. Tais experiências são sempre religiosas, pois o Mundo é sagrado. Para chegar a compreendê-las, é preciso ter em mente que as principais funções fisiológicas são suscetíveis de se transformar em sacramentos. Come-se ritualmente, e a alimentação é diversamente valorizada segundo as diferentes religiões e culturas: os alimentos são considerados sagrados, ou um dom da divindade, ou uma oferenda aos deuses do corpo (como é o caso, por exemplo, da Índia). A vida sexual, como vimos, também é ritualizada e, em conseqüência, assimilada aos fenômenos cósmicos (chuva, semeadura) e aos atos divinos (hierogamia Céu-Terra). Por vezes, o casamento é valorizado em plano triplo: individual, social e cósmico. Por exemplo: entre os Omaha, a aldeia é dividida em duas metades, chamadas respectivamente Céu e Terra. Os casamentos só podem ser realizados entre as duas metades exógamas, e a cada novo casamento repete-se o hieros gamos primordial: a união entre a Terra e o Céu" (ELIADE, 2001, p. 139).

3 Veja-se o que ele nos diz sobre o tema: "Pessoas religiosamente surdas vivem em mundos rasos e chatos, movimentam-se entre coisas transparentes (porque em tese inteiramente explicáveis), e dirigem-se para a morte que torna absurdos os mundos, as coisas e a própria vida. A capacidade religiosa torna profundo o mundo, opacas as coisas (porque nunca inteiramente explicáveis), e torna portanto obscura a visão antes clara do mundo, como a contemplação da paisagem torna obscura a visão clara dos mapas” (FLUSSER, 2002, p. 17). 
a infância, aquela hora do dia, mais um galo cantando,

a ocre, a marrom, a roxeada. Um pasto,

não tinha certeza se uma vaca

e o sarilho da cisterna desembestado, a lata

batendo no fundo com estrondo.

Quando insistiram, vem jantar, que esfria,

ele foi e disse antes de comer:

"Qualidade de telha é essas de antigamente".

O poema nos fala de um acontecimento ordinário: um homem, deitado em sua cama, olha para o telhado enquanto ouve ruídos que cotidianamente ali estão. Entretanto, de alguma forma, a substância do mundo se deixa captar nesse instante banal e um despropósito polifônico de signos salta da tela do mundo para configurar uma composição em que vida e poesia tornam-se uma mesma coisa: estranhamento e mistério.

O cotidiano perde sua pacificidade e ganha contornos mágicos e obscuros: a face de Deus, atingida pela brutalidade das coisas, se mostra, sendo que a epifania é dada pela contemplação de uma beleza que extrapola nossos conceitos de harmonia e de equilíbrio, apresentando-se na pequenez do cotidiano, afinal, se "A poesia é estranheza que a coisa me provoca; uma estranheza fundada na beleza” (PRADO, 2004), essa beleza é trágica, porque experimentada pelo homem-humano no enfrentamento de sua temporalidade e absoluta solidão em face do mistério das coisas que são, em si mesmas, impenetráveis. Entretanto, pelo enunciar poético as coisas se dão sem negaceios e mesmo a contemplação de um telhado pode ser uma experiência de religação com a finitude de seu existir e com o mundo, devolvido a si mesmo, desestrumentalizado. Em um outro trecho, agora retirado de sua prosa poética, a personagem Maria da Glória irá refletir sobre experiências similares:

A mulher tinha um vestido esverdeado, punho e gola bordados à máquina. Glória olhou, experimentando: não é pensamento, nem sensação, são os dois juntos, alguma coisa que preciso reter para contornar mas que escapa sempre. Seria uma visão? É delicioso e redime tudo como a paixão de Cristo nos redime. Seria a poesia face a face? (PRADO, 1999).

Quer seja em relação à poesia ou à prosa, há em Adélia uma clara consciência desse aspecto sagrado da poesia - "Rastro de Deus, ar onde ele passou, 
casa que foi Sua morada a poesia é" (PRADO, 1999). Vejam-se também os trechos a seguir, também de Cacos para um vitral: "No caderno de Glória: um romance é feito de sobras. A poesia é núcleo. Mas é preciso ter paciência com os retalhos, com os cacos. Pessoas hábeis fazem com eles cestas, enfeites, vitrais, que por sua vez configuram núcleos" (PRADO, 1999, p. 142).

\section{E agora Violeta, de Os componentes da banda:}

[...] meu desejo é ter o resto da vida sem nenhuma perturbação, pra emendar os pedaços de tudo o que já senti e pensei, fazer uma peça inteira, começo, meio e fim. Quando faço uma boa música, de certa forma ela cristaliza para mim alguma coisa, me religa a uma parte da qual fui separada (PRADO, 1999, p. 217).

Ao que parece, Adélia Prado confere à poesia o estatuto de elemento cosmogonizante, que emendaria os cacos fragmentados da existência em um todo orgânico, ainda que apenas experienciável apenas em instantes epifânicos, tal qual na experiência religiosa. "Querendo uma coisa, tem que se largar mão de outra? A minha boca arada é de inteiro que gosta" (PRADO, 1999, p. 43). É um desejo de inteireza que move as protagonistas da prosa adeliana - que na verdade parecem ser uma única e mesma personagem que se desdobra nos cinco romances ${ }^{5}$ - em um périplo para assumir a sacralidade do corpo e alcançar a santidade. A inteireza, que parece ser outro nome para a santidade, compreende um estado de sentir e de existir que une o inteligível, o ético e o estético, e parece ser tanto a anulação da dicotomia corpo/alma quanto a recusa à fragmentação entre sensível e cognoscível. Assim, nos diz a mesma Maria da Glória:

Desde a sua juventude invejava as amigas que comiam comendo, namoravam namorando e até mesmo colavam colando, com afinco e esmero, confundidas

4 PRADO. Solte os cachorros. Romance de1999.

5 Para Eliana Yunes, os quatro primeiros romances de Adélia, "Lidos em seu conjunto, parecem ser um único romance, com uma única personagem feminina em processo de construção e revelação, não importa que os nomes mudem, nem que se alterem os narradores em primeira ou terceira pessoa. Como se fossem quatro evangelhos, vão narrando a caminhada de paixão, morte e 'ressurreição' de uma mulher, às voltas com o cotidiano doméstico, com aspirações de alma grande, aflições e agonias que, num crescendo, atingem um estado epifânico, de quase êxtase, em descobertas que vão do corpo à linguagem" (2004, p. 33). 
elas próprias com o objeto de suas ações. Como o pai na mesa, batendo o osso no garfo para tirar o tutano, de tal modo embebido e completo que ela entendia que era uma forma, o inteiro sem fragmentos (PRADO, 1999, p. 123-124).

Felipa, protagonista do último romance de Adélia, retoma a reflexão angustiada de Glória, duvidando da naturalidade dos gestos humanos, desses incapazes de verdade: os antinaturais por natureza. ${ }^{6}$

Queria fazer coisas sem a consciência de fazê-las, como meu pai. Era assim ele porque nunca ia ao cinema? Seus atos, pelo menos quando não estava em frente de mulher, eram atos puros, sem enfeite nenhum. Eu nunca me livro, será meu natural o saber que não o sou? Pois mexo os olhos segundo uma idéia como mexer os olhos. Sou mais humana que ele? Mas mexer os olhos de maneira inconsciente é bastante animal, mas não é também aí que somos mais felizes? Correr, andar, nadar, comer, foder. Posso falar essa palavra para Vós, copular seria falsidade insuportável e o Senhor lê nos corações, estou é rezando, não me livrando das inconveniências do Alcino Maia, que nesse momento tem todo o meu amor (1999, p. 420).

A inteireza parece estar em um estado no qual o sentir e o agir sejam coextensivos, sem intervalos ou fissuras. Porque "O mistério vai se mostrar através do corpo", o périplo das personagens adelianas em busca da integridade é uma busca pela aceitação do corpo e pelo resgate de uma harmonia entre a ação e a reflexão, por um estado além (ou aquém) do bem e do mal, mas muito próximo da alegria: "Mas estar alegre era possuir intimidade, seu corpo não era mais feito de partes, mas uma só coisa harmoniosa, ajustada, digna de amor e amar, fazer os outros felizes" (PRADO, 1999, p. 143). Aceitar o corpo é aceitar suas demandas, seus limites e deslimites, e o desafio proposto a Maria da Glória, Violante, Antônia, Felipa, Célia e às outras anônimas personagens adelianas é a sacralização do corpo e o retorno à unidade com o sagrado:

Ora, o que é o corpo? Necessitarei ainda de quantas paixões para amansar meu orgulho e me deixar ver de frente, de costas, de quatro, comendo, descomendo, sem turvar os olhos? Para isso caminho. Alguém me ensinará. Uma pai-

\footnotetext{
${ }^{6}$ Poema "Atalho", in: O coração disparado (PRADO, 2001).
} 
xão, uma grande paixão me tornará de tal forma que tanto se me dará ser... (PRADO, 1999, p. 193).

Li nas Seleções que Jesus foi crucificado nu, por que ninguém nunca falou deste acontecimento magnífico? Nenhum artista lembrou-se? Roupa de baixo com renda fina e bordados, luxo dos luxos, porque ninguém me vê, é só para honrar o corpo que Deus fez. Eu amo o corpo significa eu Vos amo Jesus meu (PRADO, 1999, p. 338).

A estratégia, mística, dessa poética é assumir o corpo como espaço sagrado onde o mistério da vida e o da morte se revelam e o encontro com a alteridade se dá, um outro que tanto pode ser o humano (e é impressionante como o tema da compaixão - o "sentir com" - é aí encenado) quanto o divino. A bússola da poesia apontará sempre para o inteiro, que é identificado com aquele a que não se predica pois nada está fora Dele: daquele Um de quem nos falam místicos de tradições religiosas diversas. Se é clara a convicção de que "Deus está no telhado. E é para isto só que se nasce, para ver seu rosto terrível nos trespassando de facas" (PRADO, 1999), a hierofania não se dá nos sítios do institucional, e, sim, no doméstico cotidiano de mulheres que assumiram um modo de vida religioso, porque sedento de uma realidade realíssima como só o pode ser aquele espaço-tempo tocado pelo sagrado. Acompanhemos a narrativa que Maria da Glória nos faz de um desses momentos:

Pressiono um desentupidor da pia da cozinha e vêm à tona grãos inchados, arroz com casca, fragmentos compactos de sabão e gordura e, sem avisos, um estado de sentir, ou de ver, não sei, que já me ocorreu olhando fotografias antigas de manequins posando em paisagens de inverno e outras mais coisas insólitas. É mais que felicidade, mais que prazer. É: prestes a explodir. É: todo ser é belo. É: tudo é tão transitório, desfatiguemo-nos. É a unidade de tudo num relance apanhada. É: tem pleno sentido ir até São Paulo atrás de um novo cosmético. É que pura bobagem tomar banho todo dia. Está lá a coisa, o ser, o deus, fora de mim, completamente outro, mas em intensa comunhão comigo (PRADO, 1999, p. 229).

Em uma obra em que é impossível dissociar o elemento religioso do cotidiano, é interessante notar o aspecto transgressivo dessa encenação do relacionamento entre o humano e o divino: Adélia nos narra uma história de 
amor que, em seus altos e baixos, busca o final feliz, que será a fusão mística e o retorno à Unidade e à continuidade, como afirma a personagem Clara, no romance $O$ homem da mão seca:

Eu já xinguei deus. O pensamento vinha e eu espantava, vinha eu espantava. Eu queria juntar deus e fedaputa, foi ficando tão apavorante, tão apavorante que eu falei de um soco: deus fedaputa. Não aconteceu nada, eu fiquei calma e a minha ruindade sumiu. Se não fizer assim não conheço Ele. Me conta de onde eu tirei a vontade de xingar Ele? Me conta. Eu não faço pecado não. Eu sou o próprio ele em carne e osso. Deus dentro de nós fica com saudade de quando não tinha feito nós e tudo era uma coisa só. A peleja do mundo é que tudo que está partido e diferente quer ficar junto e igual de novo. Se Jesus veio pra nos salvar ele sentiu a maior culpa de todos. Sentiu a enorme culpa de ter saído do pai dele, foi o homem que mais sofreu. Emprestou o corpo para Deus sofrer (1999, p. 302, grifo do autor).

O contato com o sagrado irá requerer das personagens adelianas a coragem de ir além das intermediações oferecidas pelo institucional, rompendo as barreiras morais da religiosidade envergonhada e tranquila para arriscar-se a uma experiência transgressiva e violenta em que "o ser se ponha em questão", conforme fórmula batailliana. O apelo à unidade é arrebatador, em um desejo de "conhecimento" de Deus que assume, em alguns momentos, a maliciosa acepção bíblica do verbo. Em Os componentes da ban$d a$, Violante já assegurava que "Tudo quer copular, os biscoitinhos de nata, as limas verdes. Deus é ato-puro-êxtase” (PRADO, 1999, p. 262), e aqui fica bastante plausível a interpretação batailliana do erotismo, em que o autor entende que tanto a vivência erótico-amorosa quanto a experiência mística possuem um mesmo núcleo, que é o desejo de recuperar a unidade e a inteireza míticas. Na citação acima transcrita, a personagem Clara não é a protagonista do romance, e, sim, uma personagem periférica, que possui a função de guiar a protagonista Antônia em seu caminho rumo ao pleno conhecimento de Deus, o que vai implicar uma profunda experiência de sacralização do corpo, assumindo-o como "morada divina”, muito próximo do que nos diz o apóstolo Paulo. ${ }^{7}$ Ainda a esse respeito, o poema "Direitos humanos" elabora uma interessante articulação entre o humano e o divino:

\footnotetext{
7 “Ou não sabeis vós que o vosso corpo é templo do Espírito Santo?” I Coríntios 6:19 (BÍBLIA SAGRADA, 1997).
} 
Sei que Deus mora em mim

como a sua melhor casa.

Sou sua paisagem,

sua retorta alquímica

e para sua alegria

seus dois olhos.

Mas essa letra é minha (PRADO, 2001).

Clara ensina a Antônia (a personagem em aprendizado espiritual de $O$ homem da mão seca $)^{8}$ que o corpo é santo porque é através dele que o humano se revela em toda sua grandeza e, paradoxalmente, fragilidade. A salvação do humano está em saber que muito embora esteja separado do Um, a sua integridade pode ser reconquistada quando estende suas mãos e toca o outro, encontra-se com o outro. A constatação de que Eu sou o próprio ele em carne e osso é feita com profunda reverência pelo corpo, espaço sagrado em que esse encontro com o alter pode se dar.

A ascese das personagens adelianas é um processo de progressiva aceitação do humano, culminando em um sentimento íntimo de alegria e compaixão que faz lembrar as admoestações de João, o apóstolo do amor, quando o mesmo afirma que: "Ninguém jamais viu a Deus, se nós amamos uns aos outros, Deus está em nós, e em nós é perfeito o seu amor". ${ }^{9}$ Explica-se, assim, que todo amor tenda para o único amor, que é o amor divino, e as personagens masculinas Gabriel, Lísias, Pedro, Seu Eteloi Leh, Ramón, Thomaz, Teo, Santiago, Teodoro e - condensação de todos eles - Jonathan formem um único e mesmo amor, pois, se a "alma quer copular" (PRADO, 1999, p. 262), os frutos dessa cópula são a fé, a esperança e o amor, mas, de todos, o maior deles é o amor. ${ }^{10} \mathrm{Um}$ amor que tende para a Unidade:

8 Seria interessante resgatar a intertextualidade desse romance com a narrativa bíblica, em que o homem da mão seca é personagem de um dos milagres de Jesus. O desafio proposto por Cristo a esse homem é que o mesmo "estenda as suas mãos", em uma ação impossível (como estender as mãos se o estender as mãos é a própria impossibilidade que se está tentando vencer?), se não for precedida por uma fé absoluta. Também à Antônia é feito o mesmo desafio de estender as suas mãos e tocar no "outro", em um gesto de compaixão, solidariedade e comunhão. Ver: Marcos 3: 1-5 (BÍBLIA SAGRADA, 1997), e também o romance O homem da mão seca (1999, p. 382-383).

9 I João 4:12 (BÍBLIA SAGRADA, 1997).

${ }^{10}$ Assim o diz o apóstolo Paulo: "Agora, pois, permanecem a fé, a esperança e o amor, estas três, mas a maior destas é o amor”. I Coríntios 13:13. (BÍBLIA SAGRADA, 1997). 
A letra de Teo é inacreditável, encho páginas e páginas copiando ele, imitando seu traço sem nenhum enfeite. Escreve do mesmo jeito de quando tinha quinze anos. Um 'eme' é um 'eme', é só um 'eme'. Não é uma montanha, nem uma cobra disfarçada, nem um rio, é uma letra que serve para escrever minha (adorada Antônia), morto (de saudade), mel (de abelha), mala (de viagem). Feliz Natal e Próspero Ano-Novo foi o que pôs num cartão com neve, trenó e renas quando éramos noivos. Quero ser como o Teo. Deus! Estou escrevendo Teo, mas falando de Thomaz, a letra dele é que é assim tal qual descrevi. Foi ele quem me mandou o cartão! Já me aconteceu outras vezes. O que me comanda não gosta de divisões (1999, p. 317, grifo do autor).

Quando a epifania acontece é porque o processo de ascese se completou e o humano estará de tal modo próximo do sagrado que desejá-lo será desejar a Deus; a esse respeito note-se o relato que Violante faz do momento posterior a uma experiência onírico-epifânica:

Tenho sonhado com peixes e três ou quatro vezes com miúdos demônios que exorcizo, pequenas limpezas depois da limpeza grossa, da faxina de fundo que sofreu minha vida. Tenho também escrito muitos textos como o da palavra soturno - que não precisam de música -, breve me nomearei em toda a extensão, sem me envergonhar nem sofrer. ${ }^{11}$ Que profunda alegria eu sinto, que desejo profundo de chorar, de ser boa pro Pedro, pros meninos, de ser para Pulchra, Beta e Alberto uma insubstituível irmã. No dia em que as coisas consertaram, eu vinha da roça com Pedro, o poente pejado de nuvens cinza-azulado que ocultavam o sol. No meio delas, uma cavidade abria-se em forma de coração de intenso e luminoso amarelo, um coração divino dardejando. Tive certeza naquela hora: o Senhor nos ouve, nem um só gemido nosso lhe escapa. Começava a ser doce estar na cruz, alguma coisa em mim desatava-se, viciosas nós amoleciam, tocar Pedro era tocar em Deus, o tempo todo dentro de nós e eu sem perceber. Por isso Ismália diz resoluta: o seu desejo é o desejo de Deus. Eu estava crescendo como borboleta dentro da lagarta, compreendia palavras que toda vida ouvira, repetira e mesmo ensinara, só agora, vendo no céu uma claridade entre nuvens, em forma de coração intenso e luminoso amarelo. O Criador dizia à criatura: amo-te. Não tive medo da morte e respondi: eis-me (PRADO, 1999, p. 252, grifo do autor).

\footnotetext{
${ }^{11}$ Note-se aqui mais uma vez a presença do tema obsessivo: a difícil aceitação do corpo com suas excreções e limites.
} 
A narrativa junta elementos que foram elaborados em todo o périplo dessa e de outras mulheres retratadas por Adélia, estando esses elementos diretamente relacionados com aquilo que denominamos de tríade adeliana: erotismo, mística e morte. Os símbolos cristãos (nesse caso, os peixes); a presença da poesia como linguagem própria para a experiência mística; a aceitação do corpo; a comunhão com o divino, implicando profunda compaixão pelo humano e alegria tão intensa que não abole o sofrimento ou a tragicidade do existir; e o amor humano como hipóstase do amor divino são alguns dos temas abordados nesse trecho, temas que estarão presentes em toda sua obra, quer em verso ou em prosa, confirmando um desejo de cosmogonização do caos cotidiano de forma integrada e plena de significado, inclusive no que diz respeito à forte consciência da temporalidade extrema que somos, topos dos mais importantes nessa autora.

Todos esses aspectos temáticos não são alheios ao eixo fortemente integrado erotismo-mística e morte. À palavra poética parece ser dado um poder cosmogonizante que emenda esses cacos e compõe um vitral (Cacos para um vitral é o nome do segundo livro de prosa de Adélia) no qual o rosto que se desenha é um amálgama entre humano e divino. Não é gratuito, portanto, que a poesia seja considerada face de Deus, verbo encarnado, possibilidade de redenção e transubstanciação, testemunho e oráculo, face que se deixa fustigar pela brutalidade das coisas. E mais uma vez podemos perceber que nessa poética o sagrado reconcilia violência e pathos, deixando os átrios assépticos das catedrais para se encontrar face a face com o humano.

\section{Palavras que doem feito um prazer}

O momento epifânico, que de outro modo se perderia no fluir temporal, encontra na poesia seu repouso, segundo afirma a própria Adélia: "Qualquer arte - pintura, música, cinema, literatura - onde eu consiga falar da minha pequena dor pessoal, do meu pequeno medo, do meu pavor, do meu pânico, da minha doença, da minha paixão; onde eu encontre uma linguagem para isto, um signo, me descansa" (PRADO, 2004). A poesia assume também a função de fixar o mundo e as realidades nele vividas, em especial a beleza, protegendo-a da corrosão do tempo e da morte, na verdade, enganando o próprio tempo, abrindo uma fissura por meio da qual poeta e leitor podem escapar da história e entrar no tempo mítico-religioso, trans-histórico. O poema "A rosa mística" é paradigmático para se compreender o caráter cosmogônico e sagrado que a palavra poética assume nessa autora, veja-se: 
A primeira vez

que tive consciência de uma forma

disse à minha mãe:

dona Armanda tem na cozinha dela uma cesta

onde põe os tomates e as cebolas;

começando a inquietar-me pelo medo

do que era bonito desmanchar-se,

até que um dia escrevi:

'neste quarto meu pai morreu,

aqui deu corda ao relógio

e apoiou os cotovelos

no que pensava ser uma janela

e eram os beirais da morte.

Entendi que as palavras daquele modo agrupadas

dispensavam as coisas sobre as quais versavam,

meu próprio pai voltava indestrutível.

Como se alguém pintasse

a cesta de d. Armanda

me dizendo em seguida:

agora podes comer as frutas.

Havia uma ordem no mundo,

de onde vinha? [...] (PRADO, 1987).

A palavra poética magicamente institui um reino que, nos termos de Octávio Paz, faz com que o nomear instaure o ser, tornando indestrutível o fato poético, transformando-o em linguagem epifânica que revela a beleza do mundo. A religiosidade que permeia essa poesia estende-se aos poemas metalinguísticos, em que é radical a aproximação entre poesia e epifania, em harmonia com uma tradição cristã que postula a identificação entre o Logos e o divino na declaração de que "No princípio era o Verbo e o Verbo estava com Deus, e o Verbo era Deus"."

No poema "Antes do nome", transcrito a seguir, há uma separação entre palavra e Palavra, em que a primeira é êmula do universo linguístico referencial e a segunda, muleta que nos apoia, conduz-nos a universos mágico-míticos onde a lógica não impera e é possível, portanto, o entendimento

12 João 1: 1 (BÍBLIA SAGRADA,1997). 
daquilo que se inscreve no campo do sagrado. Encena-se o mítico tempo do nascimento da palavra, que é apenas disfarce do inefável segredo divino, do silêncio do inarticulado, da Palavra:

Não me importa a palavra, esta corriqueira.

Quero é o esplêndido caos de onde emerge a sintaxe,

Os sítios escuros onde nasce o "de"; o "aliás",

O "o", o "porém" e o "que", esta incompreensível

muleta que me apóia.

Quem entender a linguagem entende Deus

cujo Filho é Verbo. Morre quem entender.

A palavra é disfarce de uma outra coisa mais grave, surda-muda,

foi inventada para ser calada.

Em momentos de graça, infrenqüentíssimos,

se poderá apanhá-la: um peixe vivo com a mão.

Puro susto e terror (PRADO, 1986).

A palavra almejada é aquela que recupera suas características mágicas de condensar a percepção sensível em pontos mínimos, absolutos e exatos, rejeitando o isolamento, a sistematização e a associação de conceitos (a percepção abstrata da coisa) própria do pensamento lógico-teórico (CASSIRER, 2000, p. 52). Nos sítios escuros o poeta se embrenha à caça da palavra que revele o ser a ele mesmo, tornando possível a compreensão do Logos divino. A palavra poética é mística, sagrada, na medida em que rejeita seu poder de nomeação referencial e reconcilia nome e coisa, conforme nos lembra Foucault:

[...] O louco, entendido não como doente, mas como desvio constituído e mantido, como função cultural indispensável, tornou-se, na experiência ocidental, o homem das semelhanças selvagens. [...] é aquele que se alienou na analogia. É o jovem desregrado do Mesmo e do Outro [...] Segundo a percepção cultural que se tem do louco até o fim do século XVIII, ele só é o Diferente na medida em que não conhece a Diferença; por toda parte vê semelhanças e sinais de semelhanças; todos os signos para ele se assemelham e todas as semelhanças valem como signos. Na outra extremidade do espaço cultural, mas totalmente próximo por sua simetria, o poeta é aquele que, sob as diferenças nomeadas e cotidianamente previstas, reencontra os parentescos subterrâneos das coisas, suas simi- 
litudes dispersadas. Sob os signos estabelecidos e apesar deles, ouve um outro discurso, mais profundo, que lembra o tempo em que as palavras ainda guardavam a semelhança das coisas: a Soberania do Mesmo, tão difícil de enunciar, apaga na sua linhagem a distinção dos signos (2002, p. 68).

A esse respeito, Margarida Salomão, já no livro de estreia de Adélia, em 1976, afirmava que a poeta tem um verdadeiro horror a abstrações que a põe em companhia de Octávio Paz, para quem o poema não representa, mas apresenta o mundo. O poema não quer dizer nada além daquilo que ele é: da coisa que ele é.

[...] a descontinuidade entre palavra e coisa, detectada por Foucault no século XVII - descontinuidade que é responsável por tantos desiquilíbrios: ora a palavra é maior que a coisa, ora a coisa é maior que a palavra -, essa descontinuidade simplesmente é abolida pela obra e graça de Adélia Prado. As palavras, então, são tratadas como coisas: específico é o som de que dispõem; particular a estrutura que fiam (SALOMÃO, 1986).

As coisas falam, cabe ao poeta ouvir por nós seu discurso, "a mensagem secreta,/o inefável sentido de existir” (PRADO, 1991, p. 195), cumprindo seu papel de profeta e atalaia, como se vê no poema "O nascimento do poema", transcrito a seguir, em que coisas e palavras se fundem na imagem poética, arremessando o leitor ao coração da poesia. Os homens não inventaram as línguas, constata a poeta, pelo simples fato de que a língua os precede, e a poesia faz com que nos lembremos de que é na língua que construímos nossas moradas, daí o caráter litúrgico e profético da palavra poética, palavra que se encontra perigosamente próxima do inarticulado e do inefável, como em "O nascimento do poema”:

O que existe são coisas

Não palavras. Por isso

te ouvirei sem cansaço recitar em búlgaro

como olharei montanha durante horas,

ou nuvens.

Sinais valem palavras,

palavras valem coisas,

coisas não valem nada. 
Entender é um rapto,

é o mesmo que desentender.

Minha mãe morrendo, não faltou a meu choro este arco-íris:

o luto ficará bem com meus cabelos claros.

Granito, lápide, crepe,

São belas coisas ou palavras belas?

Mármore, sol, lixívia.

Entender me seqüestra de palavra e coisa,

arremessa-me ao coração da poesia.

Por isso escrevo os poemas

pra velar o que ameaça minha fraqueza mortal.

Recuso-me a acreditar que homens inventam as línguas,

é o Espírito quem me impele,

quer ser adorado

e sopra no meu ouvido este hino litúrgico:

baldes, vassouras, dívidas e medo,

desejo de ver Jonathan e ser condenada ao inferno.

Não construí as pirâmides. Sou Deus (PRADO, 2001).

A poesia visceral de Adélia Prado rejeita a explicação intelectualizada e a própria versão funcional e utilitária da linguagem; a palavra anunciada cumpre a ordem do poeta Drummond - "Que cada coisa seja uma coisa bela" -, entretanto, a beleza não será entendida como perfeição, equilíbrio ou harmonia, e, sim, como representação desavergonhada desses cacos de realidade e de eventos sem glamour ou da idealização que compõem o miúdo cotidiano. O entendimento, a re-velação e a cosmogonização da irrealidade fragmentada encontram-se no coração da poesia, no faz de conta que re-cria a percepção do mundo sensível, significando-o e eternizando-o.

Um poema significativo para entender essa relação entre poesia, beleza e epifania é "No meio da noite", no qual se elabora com mestria a inserção da palavra poética no banal cotidiano, provocando um corte na realidade comum para instaurar a bruma do mistério:

Acordei meu bem para lhe contar meu sonho:

sem apoio de mesa ou jarro eram

as buganvílias brancas destacadas de um escuro.

Não fosforesciam, nem cheiravam, nem eram alvas. 
Eram brancas no ramo, brancas de leite grosso.

No quarto escuro, a única visível coisa, o próprio ato de ver.

Como se sente o gosto da comida eu senti o que falavam:

"A ressurreição já está sendo urdida, os tubérculos

da alegria estão inchando úmidos, vão brotar sinos."

Doía como um prazer.

Vendo que eu não mentia ele falou:

As mulheres são complicadas. Homem é tão singelo.

Eu sou singelo. Fica singela também.

Respondi que queria ser singela e na mesma hora, singela, singela, comecei a repetir singela.

A palavra destacou-se novíssima

como as buganvílias do sonho. Me atropelou.

O que que foi? - ele disse.

- As buganvílias....

Como nenhum de nós podia ir mais além, solucei alto e fui chorando, chorando, até ficar singela e dormir de novo (PRADO, 1986).

As palavras podem nos atropelar, mas também podem nos salvar, conforme a poeta dirá no poema "Guia": "A poesia me salvará. Falo constrangida, porque só Jesus/ Cristo é o Salvador, conforme escreveu/ um homem (sem coação nenhuma)/ atrás de um crucifixo que trouxe de lembrança/ de Congonhas do Campo" (PRADO, 1986). A palavra "singela" se destaca no ar como as buganvílias se destacavam no sonho e, como a "coisa" buganvília constituía "o próprio ato de ver", a coisa palavra ${ }^{13}$ constitui a própria experiência da linguagem, sem intervalos ou fissuras conceituais e representativas. As palavras são corpóreas, e "doem como um prazer", a palavra poética não é apenas abstração da percepção sensível de uma experiência: logo, a poeta não quer "escrever coisas com palavras"14 desejando antes palavras "que se podem comer, de tão doces/ de tão aquecidas, corporificadas", ${ }^{15}$ pois está convicta de que "o que existe são coisas/ não palavras", ${ }^{16}$ o que requer a

\footnotetext{
13 "Palavras, quero-as antes como coisas", dirá a poeta no poema "Em português", da obra $A$ faca no peito (PRADO, 2001).

${ }^{14}$ Poema "A formalística" (PRADO, 2001).

${ }^{15}$ Poema "Móbiles" (PRADO, 2001).

${ }^{16}$ Poema "O nascimento do poema" (PRADO, 2001).
} 
invenção de palavras-coisas que, ao serem agrupadas em determinada forma, dispensem "as coisas sobre as quais versavam". ${ }^{17}$

O que me parece digno de destaque é essa conciliação entre uma profunda religiosidade - que apesar de um claro diálogo com a tradição judaico-cristã não é catequética, e sim problemática - e, ao mesmo tempo, uma comovente dignificação do homem-humano. Adélia comunica um sentimento religioso que extrapola os limites de sua inserção sociocultural: não é apenas à comunidade cristã que sua poesia toca, todo aquele que "peleja por alcançar algo maior do que ele mesmo" sente-se irmanado com a convicção da poeta de que "Que a fonte da vida é Deus há infinitas maneiras de entender" ${ }^{18}$

Há na poética adeliana uma clara retomada do tema da temporalidade humana, localizando-se na contramão de um projeto moderno de afastamento e insubstanciação da morte ${ }^{19}$ ao pôr em cena a necessidade da ressignificação do viver em face da finitude. A esse respeito diz-nos a poeta: "Nas metrópoles,/ o campo-santo acaba confundido,/ rodeado de bares./ E por causa disso iludem-se as pessoas/de ter nas mãos a indomesticável". ${ }^{20}$ Veja-se o conto "Amarelos", no qual a individualização do protagonista se dá não a partir de grandes ou heróicos feitos que o mesmo tenha realizado em vida, e, sim, daquilo que o torna irmão de qualquer homem: a mortalidade.

Há um momento em que todos na sala calam-se, olhando para o bico dos sapatos. Nesta hora, qualquer acontecimento é bem-vindo. Uma borboleta gigante que saia detrás da cortina, ou um mosquito que sobrevoe o cadáver são recebidos com íntimo regozijo. Alguém pressuroso sairá a espantá-los, todos acompanhando atentos e por um minuto a dor arrefece, por um minuto descansa-se.

\footnotetext{
${ }^{17}$ Poema "A rosa mística" (PRADO, 2001).

${ }^{18}$ Poema "O modo poético" (PRADO, 1986).

${ }^{19}$ A sociedade a nós contemporânea tem feito o que pode para driblar o envelhecimento e a morte e se ainda não temos um elixir da juventude totalmente eficaz, inodoro e sem contraindicações, pelo menos a velhice já está visualmente longe dos nossos olhos, bombardeados à exaustão com a visão de corpos jovens e perfeitos. A velhice e a morte são progressivamente afastados de nosso contato visual para os hospitais, asilos e clínicas luxuosas, onde uma aparência de ordem e assepsia tenta nos proteger da dor. Entretanto, a voz da poeta insiste em nos lembrar que "a grande tarefa é morrer", do poema "Campo geral" (PRADO,1991).

${ }^{20}$ Poema "O lugar da metrópole" (PRADO, 2001).
} 
Os periquitos no viveiro começam grande algazarra e outro se lembra - socorrido - é preciso dar de comer aos bichos, botar água pro cachorro. E café?, acudirá um terceiro, é preciso fazer mais café, de madrugada esfria e antes que escureça acho bom pegar uns colchões emprestados. Qualquer providência tem um halo de cósmica dimensão porque: um homem morreu. Um homem que um dia viu na cozinha um gato de olho e pêlo amarelos e tomado de grande susto disse com inocência: sai, criatura de Deus! E por toda a vida viu neste episódio um grande acontecimento, guardando-o como a um tesouro, sem saber mesmo por quê. Recontou-o poucas vezes, reconhecendo-lhe a insubstância, pois era só aquilo: um gato de pêlo e olho amarelos, um gato que por segundos fitara-o com a mesma admiração e susto. Sai, criatura de Deus! Esta exclamação não pertencia ao morto, um homem de palavra difícil pra navegar nos sustos. No entanto ele as dissera e admirava-se enormemente que houvesse saído de sua boca. Era muito bonito? Muito bonito não dizia nada, era muito o que, meu deus? Sua mulher tinha saído, os filhos estavam na escola, ele foi pegar água na cozinha e viu o gato. Era preciso segurar aquele acontecimento que lhe devolvia as palavras, exigente. Não contou nada a ninguém naquele dia. Procurou nas tralhas dos meninos papel e lápis de cor e desenhou o gato de olhos e pêlo em amarelo, um desenho de que se envergonhava porque era muito feio e tosco, muito desajeitado. Contou pra mim o seu segredo, perdoando todos os meus pecados. Sei, porque deixei que se visse nos meus olhos, como vira ele próprio o gato. E só lhe disse isto: que visão magnífica! Ele puxou a cadeira, sentou-se e repetiu com a alegria de quem aprende língua estrangeira: pois é. Magnífica! Ficou grato para sempre, meu cúmplice. Pois esse homem morreu. Amarela está a sua face, a fraca luz da tarde, o perfil das pessoas sob a chama dos círios. Sua mulher à cabeceira deu um grande uivo, sangrando a pele do mundo: ó meu Deus! Olhei bem o seu rosto e supliquei como a que uivava, "Salva-nos porque perecemos...." Entre os pés de latão que suportavam os círios a faixa de luz amarela bateu na cruz de alumínio. Alguém cochichou: os colchões já chegaram e já fiz mais café. A morte nos visita e nós abrimos a casa, precisamos de companhia e força para chorar (PRADO, 2002, p.133-135).

Palavras. Palavras que "doem feito um prazer" ${ }^{21}$ quando operam o milagre de segurar acontecimentos que de outro modo seriam impossíveis, não de serem compreendidos, pois não é de inteligibilidade de que se trata, e, sim,

\footnotetext{
${ }^{21}$ Poema "No meio da noite" (PRADO, 1986).
} 
da experimentação do viver em sua plenitude obscura. $\mathrm{O}$ gato amarelo de olhos amarelos prenuncia o amarelo do rosto humano, da luz do fim de tarde e do rosto das pessoas tocadas pelo reflexo dos círios. A morte, enroscada na trama da vida, anuncia sua visita; a indesejada das gentes é delicada e cortês, antecipando-se através de magnífico acontecimento do qual as palavras cotidianas não davam conta, não alcançavam: "Era muito bonito? Muito bonito não dizia nada, era muito o que, meu deus?”. É preciso inventar língua estrangeira, palavras novíssimas que remetam à origem e sirvam de pontes - pontes sobre o inarticulado - entre o eu e o outro, tornando-os cúmplices do segredo mais banal: que "precisamos de companhia e força para chorar".

\section{Referências Bibliográficas}

BÍBLIA SAGRADA. Trad. João Ferreira de Almeida. São Paulo: Ed. Vida, 1997

CASSIRER, Ernst. Mito e linguagem. São Paulo: Perspectiva, 2000

CRIPPA, Adolpho. Mito e cultura. São Paulo: Ed. Convívio, 1975.

ELIADE, Mircea. O sagrado e o profano. São Paulo: Martins Fontes, 2001.

FLUSSER, Vilém. Da religiosidade: a literatura e o senso de realidade. São Paulo: Escrituras Editora, 2002.

FOUCAULT, Michel. As palavras e as coisas. São Paulo: Martins Fontes, 2002.

PRADO, Adélia. Bagagem. Rio de Janeiro: Guanabara, 1986.

. Prosa Reunida. Rio de Janeiro: Sicialiano, 1999.

. Poesia Reunida. São Paulo: Arx, 2001.

. Filandras. Rio de Janeiro: Record, 2002.

. Mística e poesia. Revista Magis - Cadernos de Fé e Cultura, Centro Loyola de Fé e Cultura/PUC, Rio de Janeiro: Edições Loyola, 2004.

SALOMÃO, Margarida. Prefácio. In: PRADO, Adélia. Bagagem. Rio de Janeiro: Guanabara, 1986

YUNES, Eliana. Para gostar de Adélia (e de Jonathan). Revista Magis - Cadernos de Fé e Cultura, Centro Loyola de Fé e Cultura/PUC, Rio de Janeiro, n. 46, set., 2004.

Recebido em 23 de fevereiro de 2011

Aceito em 29 de abril de 2011 